\title{
Biogas Reforming Conversion Character on Microwave-heating Carbon Receptor
}

\author{
Hee Gaen Song ${ }^{\odot}$. Young Nam Chun ${ }^{\dagger}$ \\ Department of Environmental Engineering, Chosun University
}

(Received November 15, 2019; Revised January 13, 2020; Accepted January 23, 2020)

Objectives: Methane $\left(\mathrm{CH}_{4}\right)$ and carbon dioxide $\left(\mathrm{CO}_{2}\right)$ are the main components of biogas and are produced from biomass gasification. These two gases are a by-product gases that can be used as an energy source and is known as a greenhouse gas that affects global warming. In order to convert the gas which is the main cause of global warming into high-quality fuel energy, the microwave reforming characteristic research was conducted. In this study, the reforming characteristics of microwave carbon receptor pyrolysis-gasification gas were investigated. In addition, reforming gas conversion characteristics according to the reforming temperature, flow rate, and $\mathrm{CH}_{4} / \mathrm{CO}_{2}$ ratio, which are the main influence variables, were studied.

Methods: Experiment was achieved in a microwave convertor which was installed a quartz tube reactor. The reactor was irritated by a microwave energy to heat carbon receptor in a sample basket which was placed at the center of the quartz tube. A simulated gas mixture of methane and carbon dioxide was fed into the carbon receptor in the reactor, and a reformed product gas was collected and analyzed using a GC-TCD.

Results and Discussion: In the case of microwave reforming of a mixture gas of carbon dioxide and methane, hydrogen and carbon was produced by thermal decomposition of methane. The produced carbon was adsorbed to the receptor and interfered with the catalytic activity. The attached carbon was reacted with the carbon dioxide by gasification reaction to produce carbon monoxide, and was cleaned to maintain a constant reforming conversion.

Conclusions: As a result, the conversion rate and the product gas yield were high when the receptor bad reforming temperature was high and the space velocity in the convertor was low. The increase in methane in the simulated gas resulted in low conversion due to carbon adsorption.

Key Words: Microwave Heating, Pyrolysis Gasification, Gas Reforming, Greenhouse Gas, Carbon Receptor 


\title{
연구논문
}

\section{마이크로파 가열 탄소 수용체의 바이오 가스 개질 전환 특성}

\author{
송희관 ${ }^{\oplus} \cdot$ 전영남 $^{\dagger}$
}

조선대학교 환경공학과

목적 : 메탄 $\left(\mathrm{CH}_{4}\right)$ 과 이산화탄소 $\left(\mathrm{CO}_{2}\right)$ 는 바이오 가스의 주성분이자 바이오매스 가스화에서 생성된다. 이 가스는 에 너지원으로 사용 가능한 부생가스이며 아울러 지구온난화에 미치는 온실가스이다. 이와 같이 지구온난화 주원인 가스를 양질의 연료 에너지로 전환하고자 마이크로웨이브 개질특성 연구를 진행하였다. 본 연구에서는 마이크로 웨이브 탄소 수용체 열분해-가스화 생성가스의 개질특성을 파악하였다. 그리고 주요 영향변수인 개질 온도, 체류 시간, $\mathrm{CH}_{4} / \mathrm{CO}_{2}$ 비 변화에 따른 개질가스 전환특성에 대해 연구하였다.

방법: 실험은 석영관 반응기가 설치된 마이크로웨이브 전환기 내에서 이루어졌다. 반응기는 그 중앙에 샘플바스 켓이 위치되어 있고 그 안에 탄소수용체를 담아 마이크로웨이브에 의한 가열을 시켰다. 메탄과 이산화탄소를 혼 합한 모사가스를 반응기로 공급하여 수용체 층을 통과시키면서 개질된 생성가스를 포집하여 GC-TCD를 사용하여 분석하였다.

결과 및 토의: 이산화탄소와 메탄의 혼합가스를 탄소 수용체를 이용한 마이크로웨이브 개질의 경우 메탄의 열적 분해 반응에 의해 수소와 탄소가 생성되었다. 생성된 탄소는 수용체에 흡착되어 촉매 활성을 방해하는데 이산화 탄소의 가스화 반응에 의해 흡착된 탄소와 반응하여 일산화탄소를 생성하고 클리닝이 되어 일정한 개질 전환이 유지 되었다.

결론 : 연구 결과 수용체 배드 개질 온도가 높은 경우와 배드 체류시간이 큰 경우 전환율과 생성가스 수율이 높은 것이 확인되었다. 그리고 처리가스 중 메탄이 증가할 경우 탄소흡착으로 인해 전환율이 낮았다.

주제어 : 마이크로웨이브 가열, 열분해 가스화, 가스 개질, 온실가스, 탄소 수용체

\section{1. 서론}

메탄 $\left(\mathrm{CH}_{4}\right)$ 과 이산화탄소 $\left(\mathrm{CO}_{2}\right)$ 는 바이오 가스의 주성분이 자 바이오매스 열분해 가스화에서 생성되는 가스의 주성분 이며 이 두 가스는 기후변화 주요 원인물질인 온실가스로 알려져 있다.

이러한 이유로 기후변화 주요 원인물질인 온실가스를 개질 기술(reforming technology)을 이용하여 양질의 연료로 전화 하는데 관심과 연구가 지속적으로 진행되고 있다. 메탄 스팀 개질(methane steam reforming)은 이미 상용화되어 산업현장 에서 적용되고 있으나 메탄-이산화탄소 개질(methane dry reforming)이 온실가스 저감과 효과적인 화학 전환 에너지로 인해 더욱 매력적인 방법으로 연구되고 있다. ${ }^{1)}$

메탄과 이산화탄소는 고온반응 조건이나 촉매를 이용 하여 수소나 일산화탄소로 전환할 수 있다. 촉매의 경우 전 이금속(transition metal)이나 귀금속(noble metal)이 촉매능 (catalytic ability)이 우수하여 광범위하게 사용되고 있다. ${ }^{2)}$ 그러나 귀금속 촉매는 가격이 비싸고, 천이금속 촉매는 탄 소침착으로 촉매의 비활성화(deactivation)가 일어나 촉매의 성능 저하의 문제가 있다. 이러한 문제로 최근에는 탄소침 착(carbon deposition)이 없고 개질 전환반응이 우수한 새로 운 촉매 개발이 진행되고 있다.

최근의 연구에서는 다양한 탄소물질(carbon material)을 이 용하여 $\mathrm{CH}_{4}-\mathrm{CO}_{2}$ 개질에 대한 연구가 진행되고 있다. 이런 다 양한 탄소물질은 대체적으로 촉매 담체나 자체 촉매로 이용 되는데, 주로 활성탄(activated carbon), 석탄 촤(coal char) ${ }^{3)}$, 반성코크스(semi-coke $)^{4)}$, 바이오 촤(bio-char) ${ }^{5)}$ 가 적용-사용 되고 있다. 이 연구들은 주로 변형된 탐소함유 촉매나 자체 탄소물질의 운전조건 및 촉매활성(catalytic activity)을 통한 개질반응 특성 등에 진행되고 있다. 기존 촉매에 비해 탄소 물질 촉매는 가격이 저렴하고 촉매활성이 높고 황(sulfur)성 분에 피독 문제가 거의 없다. 
바이오 매스 열분해를 통해 생성된 바이오 촤는 활성탄 원료 및 연소와 가스화로 사용될 수 있다. ${ }^{67)}$ 지금까지의 연구는 바이오 촤 가스화를 통한 합성가스 생산에 집중되 어있었다. ${ }^{8)}$ 바이오 촤의 가스화는 바이오 촤를 이용한 메 탄 개질의 경우 거쳐야 할 과정이다. 그렇기 때문에 탄소 가스화(carbon gasification)에 대한 개질 반응 과정에 대한 연구는 중요하다.

마이크로웨이브 가열 방식은 균일가열, 선택적 가열, 급 속가열의 특성을 가지고 있고, 기존의 열풍이나 전기가열 방식보다 에너지 효율이 우수하다. ${ }^{3)}$ 이러한 이유로 바이오 매스의 열분해/가스화, 환경 오염물질 저감 및 물질 건조 등에 적용되어 왔다. ${ }^{5)}$ 앞선 연구들을 통해 마이크로 웨이 브 가열 방식이 가스 개질 전환율이 우수하고, 탄소물질이 마이크로웨이브 수용체(microwave receptor)로서 우수한 것 이 확인되었다. 또한 탄소침착도가 감소되고 생성가스의 선택도(selectivity)가 개선됨을 알 수 있다.

따라서 본 연구에서는 야자각(coconut shell)으로 만들어 진 상용 바이오 촤콜을 마이크로웨이브 탄소 수용체(MCR; Microwave Carbon Receptor)로 사용하여 열분해-가스화 생성가스의 개질특성을 파악하였다. 개질 온도, 체류시간, $\mathrm{CH}_{4} / \mathrm{CO}_{2}$ 비 변화에 따른 개질 가스 전환특성에 대한 연구 를 수행하였다.

\section{2. 실험장치 및 방법}

\section{1. 실험장치}

연구에 사용한 마이크로웨이브 가열 개질 장치는 실험실 규모로 Fig. 1과 같이 마이크로웨이브 전환기(microwave convertor), 가스공급라인(gas feed line), 모니터링/제어장치 (monitoring \& control equipment), 샘플링/분석라인(sampling \& analysis line)으로 구성되었다.

마이크로웨이브 전환기는 전력용량이 $1 \mathrm{~kW}$ 인 마그네트론 을 멀티모드 캐비티 오븐(multimode-microwave cavity oven) 형태로 설치되었고, 전환기 내부 석영(직경 $40 \mathrm{~mm}$, 길이 $320 \mathrm{~mm}$ )으로 제작된 탄소 수용체 반응기(carbon receptor reactor: CRR)가 수직으로 설치하였다. 전환기 내부 온도는 $1,000^{\circ} \mathrm{C}$ 까지 설정 가능하며, 마이크로웨이브 탄소 수용체 내부에 열전대(thermocouple: k-type, 직경 $2 \mathrm{~mm}$ )를 삽입하 고, 컨트롤러를 연결하여 미세 제어하였다. 또한, 탄소 수용 체 내부 온도변화를 파악하기 위하여 데이터 로거(data logger: Model Hydra data logger 2625A, Fluke, USA)를 연결 하여 모니터링하였다. 탄소 수용체 샘플을 석영관 반응기 내부에 위치시키기 위하여 샘플 바스켓(sample basket)을 별 도로 상하 가변되게 하여 유입과 배출이 가능하도록 하였다.

가스공급라인은 MFC (BRONKHORST, F201AC-FAC-22-V, Netherlands)로 가스유량을 조절하여 개질가스인 이산화탄소

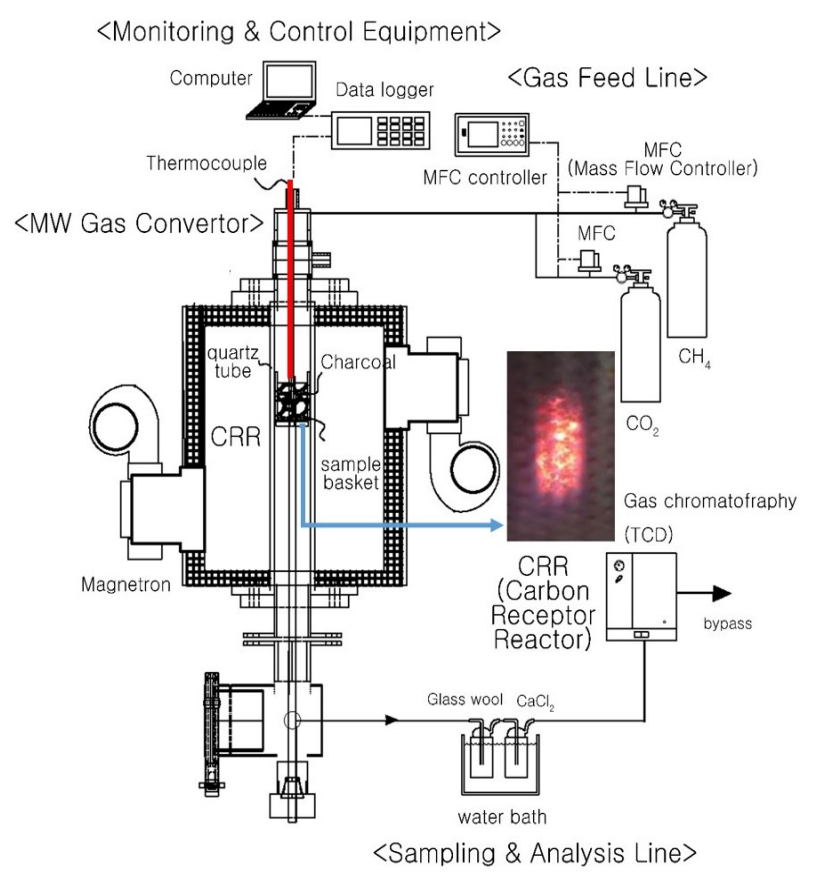

Fig. 1. Experimental apparatus for a microwave convertor.

$\left(\mathrm{CO}_{2}\right)$, 메탄 $\left(\mathrm{CH}_{4}\right)$ 을 공급하여 혼합기에서 모사 개질가스로 혼합시켜 공급하였다.

모니터링/제어장치는 가스유량 제어와 온도의 모니터링을 위하여 LabVIEW (Model LabVIEW 8.6, National Instrument, USA)를 이용하였다.

샘플링/분석라인은 유리섬유필터(Glass wool filter)와 염화 칼슘을 주입한 임핀져와 냉각기(ECS-30SS, Eyela Co., Japan) 로 구성하여 검댕과 수분을 제거하고, GC-TCD (CP-4900, Varian, Netherland)를 연결하여 개질 생성가스를 분석하였다.

\section{2. 실험 방법}

실험은 마이크로웨이브 전환기(microwave convertor)내에 석영관을 설치하여 석영관 내에 샘플 바스켓을 위치시키고 마이크로웨이브 탄소 수용체를 샘플로 하여 마이크로웨이 브를 조사시켜 가열시키고 모사가스를 석영관 반응기 내로 공급하여 수용체 층을 통과시키면서 개질된 가스를 포집하 여 분석한다.

사용된 탄소 수용체는 2 3 $\mathrm{mm}$ 로 균일하게 체 거름하여 $8 \mathrm{~g}$ 을 샘플 바스켓에 담아 전환기 중심에 위치시켰다. 그 리고 모사가스는 전체 양을 $40 \mathrm{~mL} / \mathrm{min}$ 로 일정하게 하여 공급하여 체적 공간속도(VHSV; Volumetric Hourly Space Velocity)를 항상 일정하게 되도록 하였다. 마이크로웨이브 전력 공급은 $1 \mathrm{~kW}$ 로 초기시동을 하여 샘플 온도를 상온에 서 설정 온도까지 선형적으로 증가하게 한 후 일정하게 유 지시켰다.

실험은 온도를 $900^{\circ} \mathrm{C}$ 로 일정하게 유지한 상태에서 모사가 스를 $\mathrm{CH}_{4} / \mathrm{CO}_{2}$ 비를 1.5 로 하여 유량을 $40 \mathrm{~mL} / \mathrm{min}(\mathrm{VHSV}=0.3$ ) 
Table 1. Chemical characteristics and inorganic composition of the charcoal.

\begin{tabular}{|c|c|c|c|c|c|c|c|c|}
\hline \multicolumn{4}{|c|}{ Proximate analysis (wt\%) } & \multicolumn{5}{|c|}{ Ultimate analysis $^{\mathrm{a}, \mathrm{b}}(\mathrm{wt} \%)$} \\
\hline M & $A^{a}$ & $\mathrm{VM}^{\mathrm{a}}$ & $\mathrm{FC}^{\mathrm{a}}$ & $C$ & $\mathrm{H}$ & $\mathrm{N}$ & $S$ & $\mathrm{O}$ \\
\hline 10.5 & 9.65 & 1.3 & 89.05 & 96.24 & 2.89 & 0.87 & 0 & 0 \\
\hline \multicolumn{9}{|c|}{ Inorganic composition (wt\%) } \\
\hline K & \multicolumn{2}{|c|}{$\mathrm{Ca}$} & $\mathrm{Fe}$ & $\mathrm{Cu}$ & $S$ & & & Co \\
\hline 65.43 & \multicolumn{2}{|c|}{20.57} & 9.85 & 2.08 & 1.15 & & & 0.92 \\
\hline
\end{tabular}

M: moisture, A: ash, VM: volatile matter, FC: fixed carbon

${ }^{a}$ Dry basis, ${ }^{b}$ Ash free basis

로 공급하여 기본 실험을 수행되었고, 개질에 영향을 미치는 주요 변수인 개질 온도, 공간속도, $\mathrm{CH}_{4} / \mathrm{CO}_{2}$ 비의 특성 변화에 대해 실험을 수행하였다. 개질 온도의 경우 $\mathrm{CH}_{4} / \mathrm{CO}_{2}$ 비를 1.5 로 하고 공간속도(VHSV)를 0.3 으로 고정하고 온도를 $700^{\circ} \mathrm{C} ~ 900^{\circ} \mathrm{C}$ 로 변화시켜 실험을 진행하였다. 공간속도(VHSV)는 온도와 $\mathrm{CH}_{4} / \mathrm{CO}_{2}$ 비를 고정하고 $\mathrm{VHSV}$ 를 $0.3 \sim 0.9$ 로 변화시켜 실험을 진행하였다. $\mathrm{CH}_{4} / \mathrm{CO}_{2}$ 비는 1 2.3까지 변화시켜 실험을 진행하 여 $\mathrm{CH}_{4}$ 와 $\mathrm{CO}_{2}$ 의 전환특성을 파악하였다.

개질가스 샘플링은 테들라 백을 사용하여 실험 시작부터 일정시간 간격을 두고 포집하여 분석하였다. GC-TCD에 의해 주입된 모사가스와 개질 가스의 성분을 분석하였다. $\mathrm{H}_{2}, \mathrm{CH}_{4}$, $\mathrm{CO}, \mathrm{O}_{2}, \mathrm{~N}_{2}$ 가스는 molecular sieve $5 \mathrm{~A}(80 / 100 \mathrm{mesh})$ 에 의해 그리고 $\mathrm{CO}_{2}, \mathrm{C}_{2} \mathrm{H}_{4}, \mathrm{C}_{2} \mathrm{H}_{6}$ 는 PoraPlot-Q 컬럼이 사용되었다. 야자각(coconut shell)으로 만들어진 상용 바이오 촤콜을 마이크로웨이브 탄소 수용체로 사용하였다. 탄소 수용체의 특성을 파악하기 위해 개략분석(Thermolyne Co., Type48000 Furnace/Hansung Co., HS2140 Electronic Balance)과 원소 분석(Thermofinnigan Co., EA2000/EA1112)을 수행하였다. Table 1은 탄화물 수용체인 촤콜 시료의 성분 4 가지 및 원 소분석 성분의 특성을 나타내었다. 또한, 이산화탄소 가스 화 시 탄화물 수용체의 촉매작용에 관여될 성분분석을 위 해 X-ray fluorescence (XRF) Spectrometer (Shimadzu Co., $\mathrm{ED}-720)$ 를 통해 $\mathrm{K}, \mathrm{Ca}, \mathrm{Fe}$ 등을 나타내었다.

개질 주요 대상가스인 $\mathrm{CO}_{2}$ 와 $\mathrm{CH}_{4}$ 의 전환율은 다음 식 (1) 과 식 (2)와 같다.

$\mathrm{CH}_{4}$ conversion $\left(\mathrm{X}_{\mathrm{CH} 4}\right)$ and $\mathrm{CO}_{2}$ conversion $\left(\mathrm{X}_{\mathrm{CO} 2}\right)$ for a sampling time are defined as follows:

$$
X_{C H 4}=\frac{F_{C H 4 i n}-F_{C H 4 o u t}}{F_{C H 4 i n}} \times 100 \%
$$

$\mathrm{F}_{\mathrm{CH} 4}$ in $\left(\mathrm{mL} \mathrm{min}^{-1}\right)$ and $\mathrm{F}_{\mathrm{CH} 4}$ out $\left(\mathrm{mL} \mathrm{min}^{-1}\right)$ are $\mathrm{CH}_{4}$ flow at the inlet and outlet, respectively.

$$
X_{C O 2}=\frac{F_{C O 2 \text { in }}-F_{C O 2 \text { out }}}{F_{C O 2 \text { in }}} \times 100 \%
$$

$\mathrm{F}_{\mathrm{CO} 2 \text { in }}\left(\mathrm{mL} \min ^{-1}\right)$ and $\mathrm{F}_{\mathrm{CO} 2 \text { out }}\left(\mathrm{mL} \min ^{-1}\right)$ are $\mathrm{CO}_{2}$ flow at the inlet and outlet, respectively.

\section{3. 결과 및 토의}

\section{1. 이산화탄소와 메탄 혼합가스 개질 특성}

메탄의 열적 분해 반응(식 (3))의 메커니즘에 의해 메탄은 수소로 전환되고 그 일부가 탄소로 전환되고, 이 때 전환된 탄소가 마이크로 수용체 표면에 흡착되는데 이 때문에 기 공도(porosity)가 낮아지는 것으로 보고되어 있다.") 전환반 응의 경우 일정온도 $(298 \mathrm{~K})$ 에서 $\triangle \mathrm{H}_{298}$ 가 양의 값을 가지 므로 자발적으로 반응이 일어나지 않고 계로 $75 \mathrm{~kJ} / \mathrm{mol}$ 의 에너지가 공급되어야 반응이 일어난다.

촉매를 함유한 수용체는 마이크로웨이브를 이용하여 가열 한 메탄 개질은 메탄 열분해 반응 시 생성되는 탄소의 촉매 활성층(active center)에 침착되어 수용체의 촉매 활성을 저 해하는 문제가 있다. 이와 유사한 결과는 활성탄(activated carbon), 촤(char) $)^{9}$, 카본 블랙(carbon black) ${ }^{10}$ 과 같은 여러 종 류의 탄소를 함유하는 촉매(carbonaceous-based catalyst)에 다른 연구의 결과에서도 볼 수 있다.

이 문제를 해결하기 위해서는 다음 반응(식 (4))과 같이 이산화탄소를 이용한 탄소 가스화를 통해 저감될 수 있다. 이러한 클리닝(cleaning)은 마이크로플라즈마가 탄소 수용체 배드 내에서 발생되는 마이크로웨이브 방식이 기존의 가열 방식보다 더 효과적이다. ${ }^{5)}$

$$
\begin{aligned}
& \mathrm{CH}_{4} \Leftrightarrow \mathrm{C}+2 \mathrm{H}_{2}, \quad \triangle \mathrm{H}_{298}=+75 \mathrm{~kJ} / \mathrm{mol} \\
& \mathrm{C}_{\mathrm{CH} 4}+\mathrm{CO}_{2} \Leftrightarrow 2 \mathrm{CO}
\end{aligned}
$$

위와 같은 고체-기체 불균일 반응 외에도 메탄과 이산화 탄소의 기체 균일반응(식 (5))의 건개질 반응(dry reforming reaction)에 의해 일산화탄소와 수소가 생성된다.

$$
\mathrm{CH}_{4}+\mathrm{CO}_{2} \Leftrightarrow 2 \mathrm{CO}+2 \mathrm{H}_{2}, \Delta \mathrm{H}_{298}=+260.5 \mathrm{~kJ} / \mathrm{mol}
$$

이산화탄소가 메탄보다 전환이 잘 되는 것은 메탄 열적 분해 반응(식 (3))에 의해 생성된 탄소가 수용체 기공에 흡 착되어 수용체 내부에 형성된 마이크로플라즈마의 발생을 촉진시켜 탄소 가스화 반응(carbon gasification reaction)인 


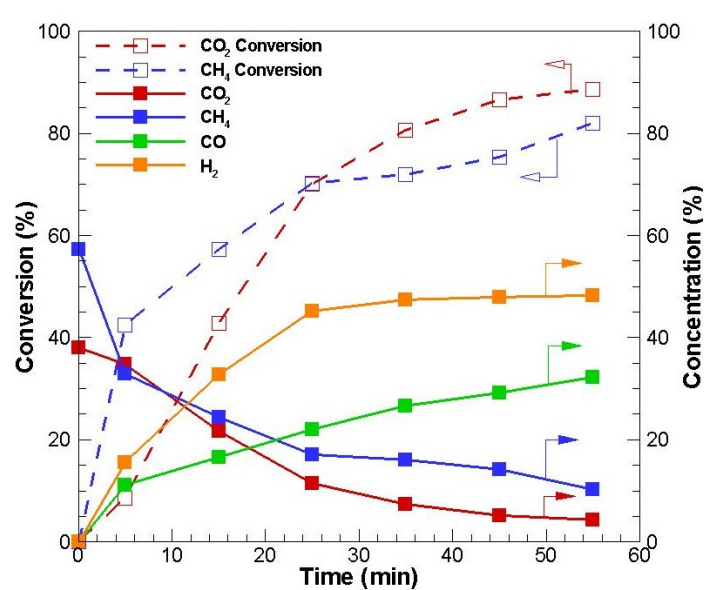

Fig. 2. $\mathrm{CO}_{2}, \mathrm{CH}_{4}$ conversion and product gas concentrations with time.

식 (6)을 유리하게 하기 때문이다. 이러한 결과는 Fidalgo et al.의 이전 연구에서도 유사한 결과를 보였다.11)

$$
\mathrm{C}_{\text {char }}+\mathrm{CO}_{2} \Leftrightarrow 2 \mathrm{CO} \quad \triangle \mathrm{H}_{298}=+173 \mathrm{~kJ} / \mathrm{mol}
$$

\section{2. 개질 온도 영향}

Fig. 2는 체적공간속도(VHSV; Volumetric Hourly Space Velocity)를 $0.3 \mathrm{~L} / \mathrm{g} \cdot \mathrm{h}$ 로 일정하게 유지하면서 탄소 수용체 의 온도를 변화시켰을 때 이산화탄소와 메탄으로 구성된 혼합가스의 개질 결과를 나타낸 것이다.

Fig. 2(a)는 $\mathrm{CO}_{2}$ 와 $\mathrm{CH}_{4}$ 의 전환율을 나타낸 것으로 세 가 지 개질 온도의 경우 모두 개질이 시작되고 전환율이 급격 히 증가한 후 거의 일정하게 유지되었다. 두 전환율 모두 개질 온도가 높을 때 그 전환율이 높은 것이 확인된다. 이 는 설정된 최종 개질 온도가 증가됨에 따라 개질반응의 반 응성이 증진되어 메탄 개질을 위한 식 (3)의 열적 분해반응 과 이산화탄소 개질을 위한 식 (6)의 탄소 가스화 반응이 증가되었기 때문이다.

기존의 가열방식(conventional heating)은 반응에 필요한 온도로 반응기 내 모든 영역을 가열 유지되어야 하지만, 마 이크로웨이브 가열방식은 CRR 내 탄소 수용체만 직접가열 되는 특성이 있다. 그러므로 마이크로웨이브 가열 방식은 탄화물 입자 체적(volume of char particle)내에서 특히 국부 고온부(hot spot)에서 반응이 증진된다고 볼 수 있다. ${ }^{12)}$

Fig. 2(b)는 각기 다른 개질 온도에 따른 생성가스의 농도 와 발열량을 나타낸 것이다. 개질 온도가 증가됨에 따라 $\mathrm{CO}_{2}$ 와 $\mathrm{CH}_{4}$ 의 전환율 증가로 인해 그 양이 감소되는 것이 확인되며 $\mathrm{H}_{2}$ 와 $\mathrm{CO}$ 의 농도는 건개질 반응(식 (5))에 의해 각각 증가되는 것을 보였다. 이때 $\mathrm{H}_{2} / \mathrm{CO}$ 비는 $900^{\circ} \mathrm{C}$ 일 때 1.72 로 개질 온도가 높을수록 그 값이 큰 것을 알 수 있었 다. 그러나 발열량의 경우는 개질 온도가 $700^{\circ} \mathrm{C}$ 일 때 19.24 $\mathrm{MJ} / \mathrm{m}^{3}$ 로 큰데 이는 메탄 전환율이 낮아 전환되지 않은 메
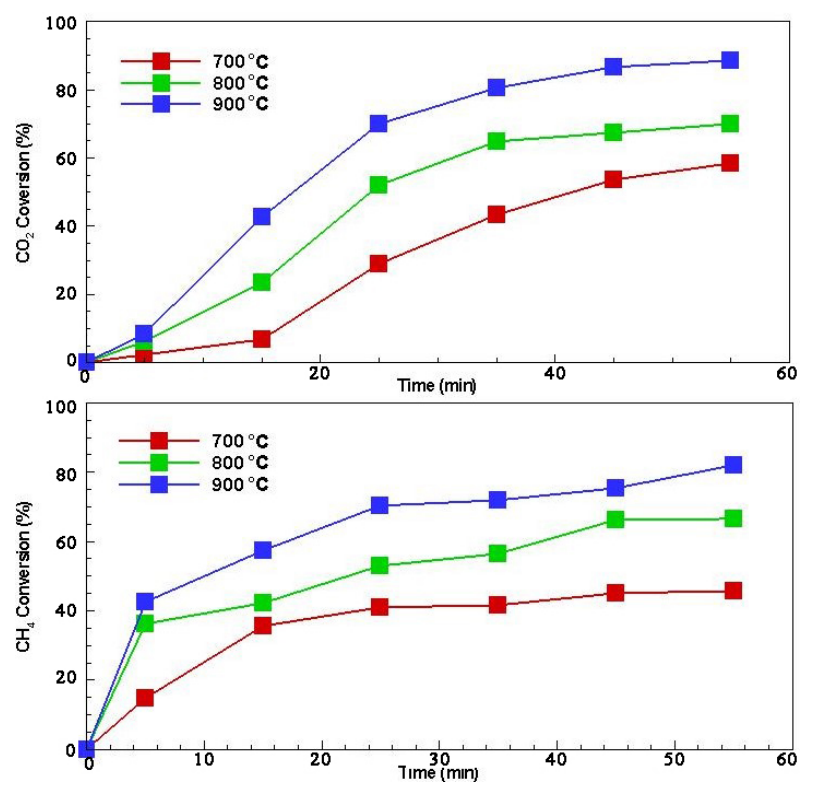

(a) $\mathrm{CO}_{2}$ and $\mathrm{CH}_{4}$ conversions

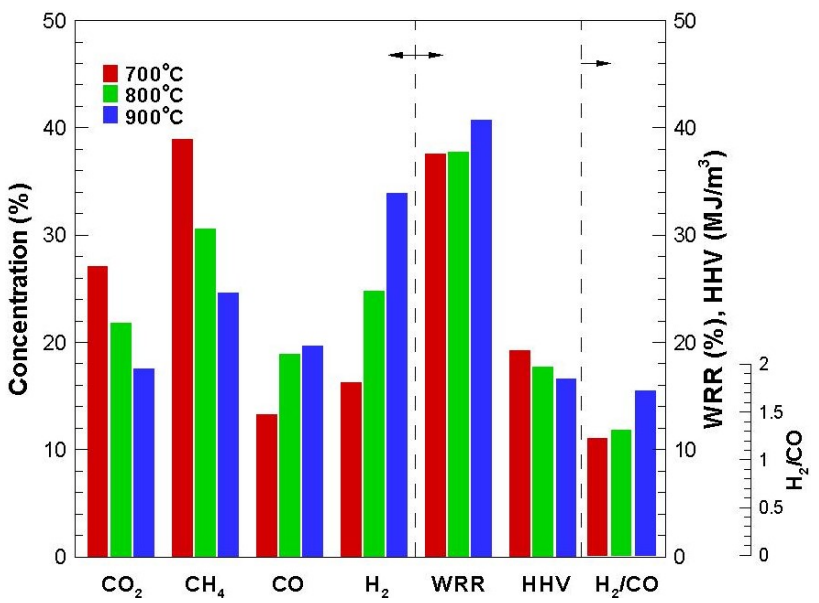

(b) Average product gas concentrations, weight reduction rate, higher heating value, and $\mathrm{H}_{2} / \mathrm{CO}$ rate

Fig. 3. Comparison of the different retention time.

탄의 양이 많기 때문이다.

\section{3. 체류시간 영향}

Fig. 3은 개질 반응기 내 탄소 수용체 배드층을 처리가스 가 통과하는 공간속도 변화에 대한 개질전환율 결과를 나 타낸 것이다.

Fig.3(a)에서 볼 수 있듯이 전반적으로 개질 패턴은 거의 유사함을 보였으며 $\mathrm{CO}_{2}$ 와 $\mathrm{CH}_{4}$ 전환율은 기존 조건인 공간 속도가 $0.3 \mathrm{~L} / \mathrm{g} \cdot \mathrm{h}$ 일 때 가장 큰 값을 보였으며 이보다 체류 시간이 짧은 공간속도 $0.9 \mathrm{~L} / \mathrm{g} \cdot \mathrm{h}$ 에서는 적은 값을 보였다. 이는 체류시간이 이산화탄소의 경우 탄소 가스화 반응 (식 (6)) 그리고 메탄의 열적 분해 반응(식 (3)) 정도에 영향 을 미치기 때문이다. 특히, $\mathrm{CO}_{2}$ 전환의 경우 $\mathrm{CO}_{2}$ 가 탄소 수용체의 미세세공으로 들어가 충분한 시간을 갖는 것이 

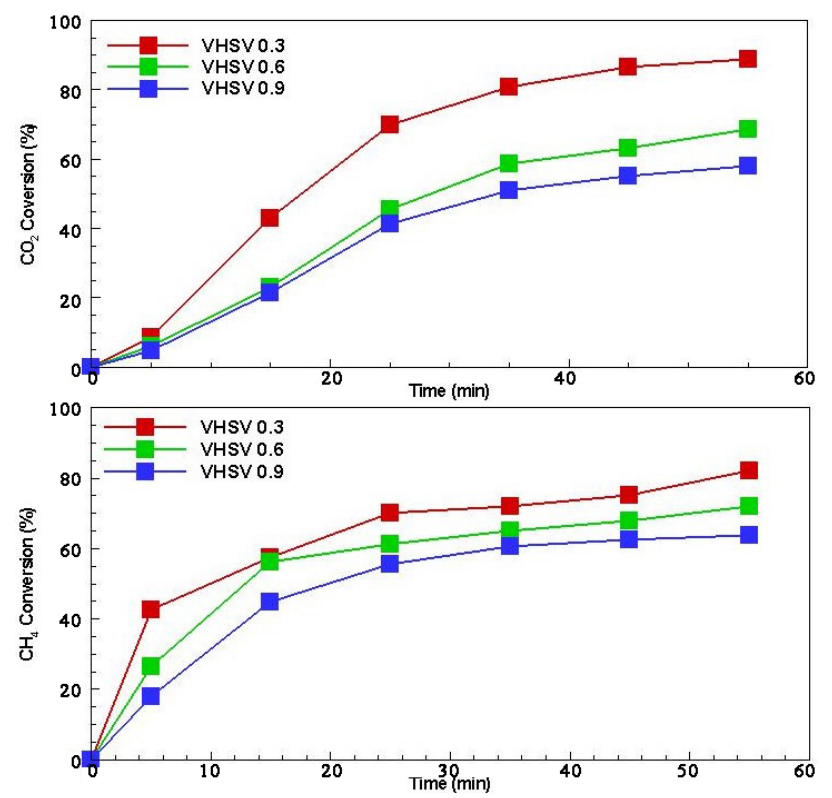

(a) $\mathrm{CO}_{2}$ and $\mathrm{CH}_{4}$ conversions

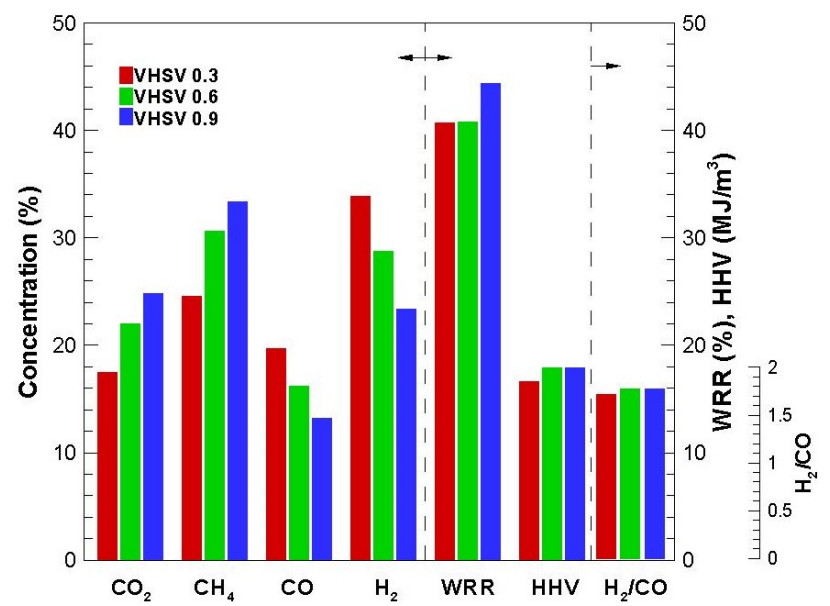

(b) Average product gas concentrations, weight reduction rate, higher heating value, and $\mathrm{H}_{2} / \mathrm{CO}$ rate

Fig. 4. Comparison of the different $\mathrm{CH}_{4} / \mathrm{CO}_{2}$ rate.

필요하여 체류시간이 긴 낮은 공간속도 $0.3 \mathrm{~L} / \mathrm{g} \cdot \mathrm{h}$ 인 경우 상대적으로 더 $\mathrm{CO}_{2}$ 전환율이 높았다.

Fig. 3(b)는 개질가스의 농도와 발열량을 나타낸 것으로 체적공간속도가 클수록 $\mathrm{H}_{2}$ 와 $\mathrm{CO}$ 의 농도가 점차 작았다. $\mathrm{CH}_{4}$ 와 $\mathrm{CO}_{2}$ 역시 전환율에서 알 수 있듯이 체적공간속도가 큰 경우 개질 반응이 상대적으로 적게 일어나는 것을 알 수 있다. 개질 가스 발열량의 경우 큰 차이는 없었으나 체 적공간속도가 클수록 전환되지 않은 메탄에 의해 발열량이 높았다.

\section{4. 처리가스 $\mathrm{CH}_{4} / \mathrm{CO}_{2}$ 비 영향}

Fig. 4는 개질 반응기 내 공급되는 처리가스의 $\mathrm{CH}_{4} / \mathrm{CO}_{2}$ 비 변화에 대한 개질전환율 결과를 나타낸 것이다.

Fig.4(a)에서 볼 수 있듯이 처리가스 중 $\mathrm{CH}_{4}$ 의 양이 증가
할수록 상대적으로 $\mathrm{CO}_{2}$ 전환과 $\mathrm{CH}_{4}$ 전환값이 낮아졌다. 처 리가스 중 $\mathrm{CH}_{4}$ 가 증가될 경우 $\mathrm{CO}_{2}$ 전환과 $\mathrm{CH}_{4}$ 전환의 감소 는 마이크로웨이브 가열 시 건조개질 메커니즘에 의해 설 명될 수 있다. 메탄 분해 반응(식 (3))으로부터 분해된 성분 인 탄소가 탄소 수용체에 흡착되는 특성과 이 흡착 탄소와 $\mathrm{CO}_{2}$ 가스화 반응(식 (4))에 의해 활성기공(active centers)을 회복(regenerating)시키는 정도 차이에 의해 영향을 받는다. 처리가스 중 $\mathrm{CO}_{2}$ 양이 감소됨에 따라 흡착탄소에 의해 막 혀있는 활성기공을 재생시키는 $\mathrm{CO}_{2}$ 의 능력(capacity)이 감 소되는데 이로 인해 $\mathrm{CO}_{2}$ 전환은 물론이고 $\mathrm{CH}_{4}$ 의 전환도 감 소되었다.

Fig. 4(b)는 개질가스의 농도와 발열량, 중량감소율을 나타낸 것이다. 처리가스 중 메탄의 양이 증가될 경우인

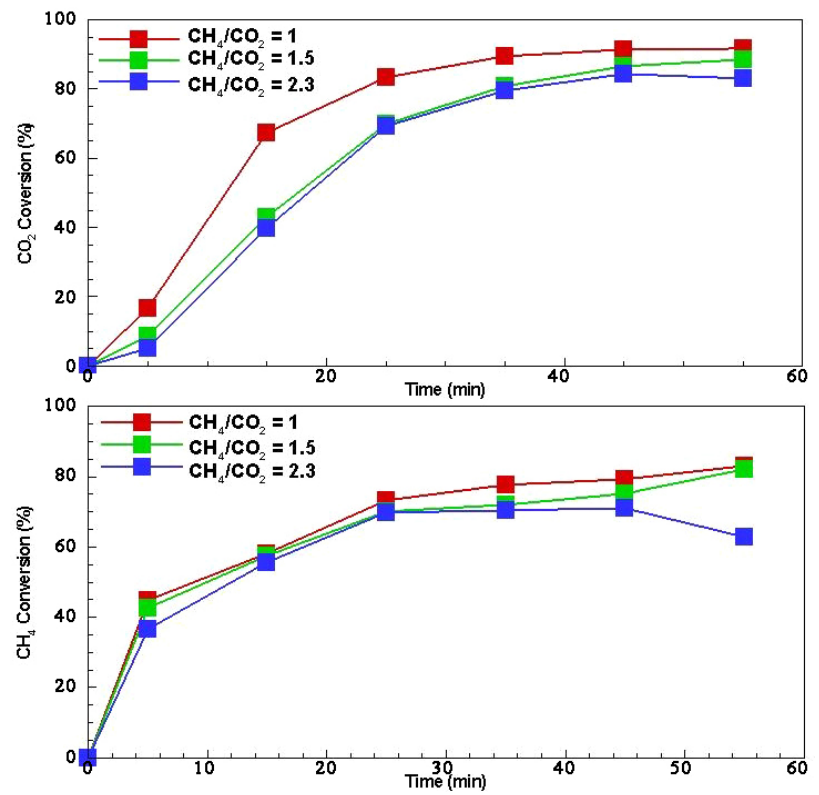

(a) $\mathrm{CO}_{2}$ and $\mathrm{CH}_{4}$ conversions

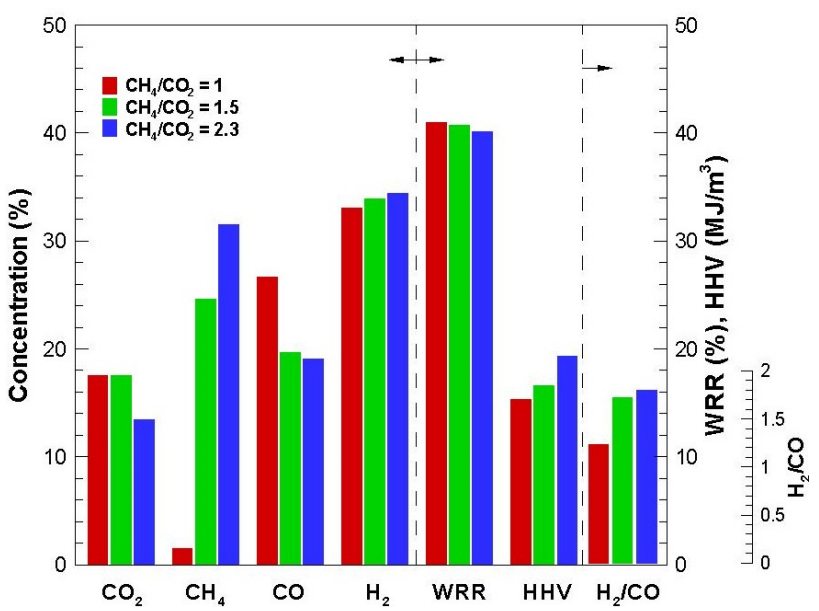

(b) Average product gas concentrations, weight reduction rate, higher heating value, and $\mathrm{H}_{2} / \mathrm{CO}$ rate

Fig. 5. $\mathrm{CO}_{2}, \mathrm{CH}_{4}$ conversion and product gas concentrations with time. 
$\mathrm{CH}_{4} / \mathrm{CO}_{2}$ 비가 증가함에 따라 생성가스인 $\mathrm{CO}$ 는 감소되었고 $\mathrm{H}_{2}$ 는 증가되었다. 그리고 전환되지 않은 메탄이 잔류하여 발열량 값이 상대적으로 큰 값을 보였다.

\section{5. 혼합가스 개질 결과}

앞의 변수들을 통해 조건에 따른 개질 영향을 파악하였다. 개질 온도 $900^{\circ} \mathrm{C}$, 체적 공간속도(VHSV) $0.3 \mathrm{~L} / \mathrm{g} \cdot \mathrm{h}, \mathrm{CH}_{4} / \mathrm{CO}_{2}$ 비를 1.5 로 일정하게 하여 개질을 진행하였다. 그 결과는 Fig. 5와 같다.

개질이 시작된 후부터 메탄 전환과 이산화탄소 전환은 급격하게 증가하였다. 우선 메탄이 열적분해 반응(식 (3)) 에 의해 수소가 생성되고 메탄으로부터 생성된 탄소는 수 용체 표면에 흡착되고 이산화탄소에 의한 탄소 가스화 반 응식(식 (4))에 의해 저감되면서 일산화탄소가 생성된다.

위와 같은 혼합가스의 전환은 마이크로웨이브 개질이 진행되면서 수소와 일산화탄소가 생성되면서 농도가 증 가하고 메탄과 이산화탄소의 농도는 감소하는 것에서도 확인된다.

\section{4. 결론}

메탄 $\left(\mathrm{CH}_{4}\right)$ 과 이산화탄소 $\left(\mathrm{CO}_{2}\right)$ 를 주성분으로 하는 바이오 가스, 바이오 열분해 가스화 가스를 양질의 연료 에너지로 전환하고 온실가스문제를 해결하기 위하여 마이크로웨이 브 개질 특성을 파악하였다.

이산화탄소와 메탄의 혼합가스를 탄소 수용체를 이용한 마이크로웨이브 개질의 경우 메탄의 열적 분해 반응에 의 해 수소와 탄소가 생성되고 생성된 탄소가 수용체에 흡착 되어 촉매 활성을 방해하는데 이산화탄소의 가스화 반응에 의해 흡착된 탄소와 반응하여 일산화탄소를 생성하고 클리 닝이 되어 일정한 개질 전환이 유지된다.

수용체 배드 개질 온도가 높을 경우와 배드 공간속도가 낮 을 경우 전환율과 생성가스 수율이 높은 것이 확인되었다.

\section{Acknowledgement}

이 논문은 2018년도 정부(교육부)의 재원으로 한국연구 재단의 지원을 받아 수행된 기초연구사업입니다(NO. 2018 R1D1A1B07040326).

\section{References}

1. L. Xu, Y. N. Liu, Y. J. Li, Z. Lin, X. X. Ma, Y. L. Zhang, M. D. Argyle, M. H. Fan, Catalytic $\mathrm{CH}_{4}$ reforming with $\mathrm{CO}_{2}$ over activated carbon based catalysts, Applied
Catalysis: General, 469, 387-397(2014).

2. B. T. Li, X. J. Xu, S. Y. Zhang, Synthesis gas production in the combined $\mathrm{CO}_{2}$ reforming with partial oxidation of methane over Ce-promoted $\mathrm{Ni} / \mathrm{SiO}_{2}$ catalysts, Int. J. Hydrogen Energy., 38, 890-900(2013).

3. G. J. Zhang, Y. Dong, M. R. Feng, Y. F. Zhang, W. Zhao, H. C. Cao, $\mathrm{CO}_{2}$ reforming of $\mathrm{CH}_{4}$ in coke oven gas to syngas over coal char catalyst, Chem. Eng. J., 156, 519-523(2010).

4. G. J. Zhang, J. W. Qu, Y. N. Du, F. B. Guo, H. X. Zhao, Y. F. Zhang, Y. Xu, Hydrogen production from $\mathrm{CO}_{2}$ reforming of methane over high pressure $\mathrm{H}_{2} \mathrm{O}_{2}$ modified different semi-cokes, J. Ind. Eng. Chem., 20(5), 2948-2957(2014).

5. A. Domínguez, Y. Fernández, B. Fidalgo, J. J. Pis, J. A. Menéndez, Biogas to syngas by microwave-assisted dry reforming in the presence of char, Energy Fuel, 21, 2066-2071(2007).

6. M. Bardalal, D. K. Mahanta, Characterisation of the pyrolysis oil derived from bael shell (aegle marmelos), Environ. Eng. Res., 21(2), 180-187(2016).

7. G. Omulo, N. Banadda, I. Kabenge, J. Seay, Optimizing slow pyrolysis of banana peels wastes using response surface methodology, Environ. Eng. Res., 24(2), 354-361(2019).

8. N. Xiao, H. Luo, W. Q. Wei, Z. Y. Tang, B. Hu, L. Z. Kong, Y. H. Sun, Microwave-assisted gasification of rice straw pyrolytic biochar promoted by alkali and alkali earth metals, J. Anal. Appl. Pyrol., 112, 173-179(2015).

9. Z. Bai, H. Chen, B. Li, W. Li, hydrogen production by methane decomposition over coal char, Int. J. Hydrogen Energy, 31, 899-905(2006)

10. E. K. Lee, S. Y. Lee, G. Y. Han, B. K. Lee, T. J. Lee, J. H. Jun, K. J. Yoon, Catalytic decomposition of methane over carbon blacks for $\mathrm{CO}_{2}$-free hydrogen production, carbon, 42(12-13), 2641-2648(2004).

11. B. Fidalgo, A. Domínguez, J. J. Pis, J. A. Menéndez, Microwave-assisted dry reforming of methane, Int. J. Hydrogen Energy, 33, 4337-4344(2008).

12. Y. N. Chun, H. G. Song, Microwave-enhanced gasification of sewage sludge waste, Environ. Eng. Res., 24(4), 591-599(2019).

\section{Authors}

\section{Hee Gaen Song}

Department of Environmental Engineering, Chosun University, Ph.D. Course Student, ORCID (i) 0000-0001-6746-3278

\section{Young Nam Chun}

Department of Environmental Engineering, Chosun University, Professor, ORCID (1) 0000-0002-7617-7705 